\title{
ASSESSMENT OF THE FINANCIAL HEALTH OF REGIONAL EMERGENCY MEDICAL SERVICES IN THE CZECH REPUBLIC USING THE BAMF MODEL
}

\author{
Ivana KRAFTOVÁ ${ }^{1}$, Lenka KAŠPAROVÁ ${ }^{2}$ \\ Institute of Regional and Security Sciences, Faculty of Economics and Administration, \\ University of Pardubice, Studentská 95, 53210 Pardubice, Czech Republic

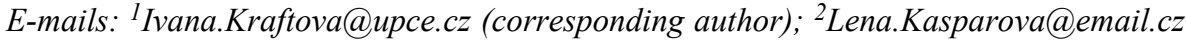

Received 24 November 2015; accepted 11 December 2016

\begin{abstract}
The focus of the paper is the evaluation of the financial health of selected public service providers. As part of the research we used a specially designed model of balance-sheet analysis for BAMF municipal companies. Used on a sample of 14 regional providers of emergency medical services in the Czech Republic from 2010-2014, we assessed the level and variability of the aggregate financial health indicator BAMF and its components, five sub-indicators. It turns out that the financial health of these subjects, although displaying significant similarities are not free of extreme values that in practice require more attention, or more precisely, deeper analysis. The authors conclude that the model is relatively easy to apply in practice and can contribute to the better financial health management of public sector bodies. At the same time, the BAMF model can be considered an addition to the theory of financial analysis.
\end{abstract}

Keywords: public sector, emergency medical service, regional distribution, BAMF model, financial health, variability.

JEL Classification: H49, H83, R53.

\section{Introduction}

The financial health of individual economic entities in the private sector has stood in the long-term at the forefront of financial managers' attention. There are a variety of approaches to the assessment, starting with the use of partial indicators that monitor various aspects of financial management all the way to complex models, which were critically evaluated in terms of the methods used by Balcaen and Ooghe (2006). It is understandable that the assessment of the financial health of subjects operating within the private for-profit sector, but also state enterprises operating on a profit basis is associated with the assessment of their growth (Gordon 1959; Andrés Alonso et al. 2005). Often, however, it is advisable to combine the application of complex models with a sensitivity analysis as there is a certain degree of uncertainty contained within the data that enter the discount models (Booth 2007). Among the most famous authors of complex models certainly belong Altman (2002), Taffler (1982) and Tamari (1966). 
The models are similar in their attempt to predict the threat of a company's bankruptcy, but they vary in the methodology used. E. I. Altman was the one who showed an exceptional ability in modifying models; the publication of his first model is dated 1968 (Altman 1968) and the last, which was inspired by Enron and WorldCom, is from 2002 (Altman 2002). However, there are also models that tend to differentiate businesses according to the sector to which they belong (Neumaierova, Neumaier 1995), in order to refine the interpretation of the results with regard to the sectoral differentiation of some financial analysis indicators (Kraftová, Sustrova 2010; Kubenka, Kralova 2013); or there are hierarchical models that allow partial results as well as the final result to be easily interpreted thanks to the selected reference value at each stage of the hierarchy (Doucha 1996).

On the other hand, the public sector providing pure and mixed public goods constitutes the producers who operate on a non-profit basis, linked to public budgets and characterized by non-excludable economic specifics (Jackson, Brown 2003). Specialists from both practice and academia have also paid considerable attention to the management of the public sector, especially its effectiveness, fairness, quality and innovation, especially since the beginning of the new millennium, and from different points of view (Kouzmin et al. 1999; Marianov, Taborga 2001; Borins 2001; Bovaird, Loffler 2003; Sullivan, Gillanders 2005; Mastalka, Saldova 2015). At the same time there are various approaches and methods used, e.g. multi-attribute benchmarking for evaluating the financial health of local governments (Galariotis et al. 2015; Halaskova, M., Halaskova, R. 2014); Data Envelopment Analysis to assess the performance in the area of public health (Foo et al. 2015) or Weighted Proximity Prestige index for the assessment of resource allocation and structure of the service providers network (Wang et al. 2014).

However, models that assess the financial health of individual producers of public goods are not widespread, while the models designed for for-profit businesses are not easily transferable to this sector. The authors failed to find literature that would contain a model for assessing the financial health of municipal companies. Therefore, their work began to deal with the construction of such a model. The first attempt was a simple classification model inspired by Kralicek Quick Test (Mrkvicka 2006), but it turned out that although this simple model evaluates financial health, it is worse at showing possible ways of improvement (Kraftová 2002). Another of the models designed specifically for entities, producers of public sector services is the BAMF model (balance-sheet ${ }^{1}$ analysis of municipal companies), which was mainly inspired by the Doucha balancing model (Doucha 1996). The BAMF model, however, respects the non-profitability characteristics of public goods producers, meeting the requirements for purposefulness, applicability and information effectiveness (Kraftová 2002). At the same time the BAMF model has undergone some development. Its original version from 2002 has been improved in

\footnotetext{
${ }^{1}$ The adjective "balance-sheet" reflects the fact that the data entered into the model are taken from two basic account statements, the statement of financial position and the statement of financial performance in the concept of IPSAS 1 (IPSASB 2016); in the Czech Republic in response to the Decree 410/2009 Coll., which implements certain provisions of Act No. 563/1991 Coll., On accounting, as amended, for some selected entities (CR 2009).
} 
order to emphasize, from the perspective of the public sector, the more significant and potentially risky areas of financial analysis (Kraftová 2007).

BAMF model applicability was initially verified on the industry-diverse sample of municipal companies. This paper presents its application on a single type, namely the organizations of emergency medical services. One reason for this choice is the discussion started in Czech professional circles over the efficiency of financial expenditure of emergency medical services. Other aspects of this problem are uncovered by Daler (2016). It is understandable that in a situation where the resources for securing public services in the area of social and healthcare are increasingly scarce, it is necessary to pay more attention to the financial health of the care providers, including the providers of emergency medical services. Both founders and providers should have a relatively easy tool for monitoring the status and deviations from the "norm". The aim of the paper is to assess the applicability of the BAMF model for this purpose on a segment of ambulance providers in the Czech Republic and to verify the following hypotheses: i) emergency medical services providers in the Czech Republic demonstrate financial health as measured by the aggregate BAMF indicator; ii) the variability of this aggregate financial health indicator is low; iii) the variability of each sub-indicator is also low.

\section{Emergency medical service as a type of public sector entity}

According to Act No. 374/2011 (CR 2011), an emergency medical service is a health service "that provides, based on an emergency call, pre-hospital emergency care to people with severe health or an immediate threat to life". An important attribute of its operation is to ensure the preparedness to provide this service in dealing with emergencies and crisis situations. The emergency medical service is one of three basic components of the Integrated Rescue System (together with the Fire and Rescue Service and the Czech Police). But it is the only one, which is built on a regional basis in the sense that its founder is always a relevant regional self-governing unit, a region. An important parameter of the emergency medical service is its availability, the importance of which, in terms of quality and effectiveness, is discussed by Janosikova et al. (2015). The organizational structure of each provider of this medical service, reflected in the planned coverage of the region, is subject to the parameter of availability (outbound bases with ground teams and in eight cases also with air teams).

Regional emergency medical services are contributory organizations with multi-source funding. The largest part is taken up by the payment of professional healthcare according to the list of medical treatments that have point values assigned to them by health insurance companies on a contractual basis; operating costs that cannot be paid by health insurance are covered by contributions from the founder, the region; investment costs are usually also covered by donations from the founder, the region. In addition, non-investment subsidies are provided from the state budget to finance the preparedness of these entities to deal with emergencies and crisis situations. In this way, the state, which imposes a legal obligation, contributes financially to the creation of conditions for its fulfilment. 
Founders of the emergency medical services, regions, allow the providers to run, in addition to their main activity (on a non-profit basis) also an ancillary activity, i.e. an economic activity on a for-profit basis, but in reality, this economic activity is not carried out (this finding is important for the modification of the model that evaluates financial health). The fact that in the Czech Republic there are (in line with the number of regions) fourteen entities of the same kind, allows, apart from the actual assessment of the financial health of individual regional emergency medical services, also their comparison, or the application of a type of benchlearning in practice in this area.

Regional distribution of emergency medical services providers can be described using relevant indicators, which include both parameters that influence the degree of a need for appropriate health services: the number of inhabitants in the region and its area; and parameters that represent the material-technical, organizational, professional, and financial resources necessary to fulfil this need.

\section{Research methodology: the BAMF model}

In order to assess the financial health of individual emergency medical service providers in the Czech Republic and to subsequently carry out their comparison, the abovementioned BAMF model was used, as modified in 2007 (Kraftová 2007).

The BAMF model is based on the concept of balance-sheet analysis while at the same time it takes into account the specifics of the producers of public goods, who can be described as municipal companies. The model is simple enough and to some extent even flexible. The basic assumptions of the BAMF model include:

- The included indicators are generally positively assessed in terms of their growth tendency.

- The indicators are set up in such a way that their optimum value is around " 1 " (i.e. reference value).

- The model does not take into account the significance of each indicator; the overall result is a simple arithmetic average.

- The BAMF model only uses financial statements data, i.e. statement of financial position and statement of financial performance data. For the calculation of an indicator it is necessary to have the data from the current and previous periods available (for the indicator of activity, simplified averages of opening and closing balances, and for the calculation of an increase in revenues and expenses in one of the indicators for profitability, the yield variator).

- The model has been designed for municipal companies and modified depending on whether they carry out complementary activity or not.

The BAMF model from 2007 includes financial analyses, which (according to experience and control calculations made by the authors) best capture the specifics of municipal companies, namely liquidity and activity, their links to the evaluation of results, cash flow management; (for example, the area of financing often used in the profit sector is inappropriate, and specifically with regard to the rules laid down for non-profit municipal companies); autarchy is also used, in which a priori contemplated balance 
of revenues and expenses of non-profit companies is embedded; performance, which evaluates the de facto structure of added value as a more appropriate indicator than net income in this case. Looking at the dynamics or the sensitivity of revenues in relation to cost development is enabled by a yield variator. And given that municipal companies can carry out ancillary profitable economic activities with the consent of the founder, a specific indicator of profitability is also included for these cases. It is designed to indicate the competence of a municipal company to cover loss from the main activity with its profit from ancillary business activities, which is a generally applicable rule (in the text below, the indicators are described in more detail) ${ }^{2}$.

The basic form of the BAMF model designed for entities who carry out profitable ancillary economic activity (BAMF*) is captured by formula (2), for entities who do not carry out such an activity (BAMF) by formula (3).

$$
\begin{gathered}
\mathrm{BAMF}^{*}=\frac{L i+A c+A u+P e+V y+P r}{6} ; \\
\mathrm{BAMF}=\frac{L i+A c+A u+P e+V y}{5},
\end{gathered}
$$

where: $L i$ - liquidity; $A c$ - activity; $A u$ - autarchy; $P e$ - performance; $V y$ - yield variator; $\mathrm{Pr}$ - profitability.

The BAMF model evaluates not only traditionally analyzed areas and financial analysis indicators $(L i, A c)$, but also areas or indicators not included in the traditional concept of financial analysis, but crucial for municipal companies $(\mathrm{Au}, \mathrm{Pe}, \mathrm{Vy}, \mathrm{Pr})$.

Swift (quick) liquidity ${ }^{3}$ marked with $L i$, see formula (4), should be around a value of 1 , which presents a balance between current receivables and current payables. A quick liquidity value below one indicates that there is a danger of insolvency, a value of the indicator that exceeds the value of one means that funds are ineffectively tied up in cash and receivables, which "lie fallow" and do not increase their value by being repeatedly used in the production process.

$$
L i=\frac{F A+C R}{C P},
$$

where: $F A$ - financial assets; $C R$ - current receivables; $C P$ - current payables.

The activity area is represented by an indicator that detects the degree of consistency between receivables due dates and payables due dates, in relation to revenues and expenses, marked with $A c$, see formula (5). The indicator includes only current assets and liabilities with respect to benchmarking with an annual cumulative value of revenues, or expenses. A value of around 1 represents an equilibrium situation between the two

\footnotetext{
${ }^{2}$ It should be noted that while liquidity and activity indicators are frequently used indicators in similar models related to profitable companies (Neumaierova, Neumaier 1995; Doucha 1996), the other parameters of the BAMF model are the author's own design (Kraftová 2007).

${ }^{3}$ Sometimes we talk about the so called Quick test (or Q-test) for financial health, which is also sometimes called the Acid test (Ruckova 2014).
} 
turnaround periods. A value that is considerably higher than 1 represents a situation where the municipal company's receivables have a much longer due date period and in relation to the level of revenues they exceed the due date period of the company's payables related to a particular level of expenses. A municipal company should manage this area towards reducing the due dates of their receivables and conversely extending the due dates of their payables. The opposite situation indicates that a municipal company has room for extending their receivables due dates without directly threatening its solvency.

$$
A c=\frac{A C R / R}{A C P / E},
$$

where: $A C R$ - average current receivables; $R$ - revenue; $A C P$ - average current payables; $E$ - expenses.

Autarchy (a measure of autarchy $A u$ ) reflects the degree of self-sufficiency for a municipal company. When evaluating the degree of autarchy it is necessary to consider two conditions, or premises, which (if not met) complicate the evaluation of these modified profitability indicators. They are: the premise that demand is fully saturated by supply and the premise that there is no private company that would need less input for the same level of output. Depending on the data used, autarchy can be assessed either on a revenue-expense basis or on an income-expenditure basis. Autarchy enters the BAMF model on the revenue-expenses basis from the main activity of municipal companies, see formula (6).

$$
A u=\frac{R}{E},
$$

where: $R$-revenue; $E$-expenses.

Profitability as a measure of effectiveness is one of the traditional indicators in the financial analysis of private profitable companies. In terms of municipal companies, however, it justifiably represents one of the most debated issues. Profit as such is not the reason why these companies are in operation. To calculate a profit in the concept of cost-benefit analysis is only meaningful, given the practical and methodological difficulties, during systemic or innovative changes, or large projects, but not within the context of operational management (Beria at al. 2012; Gwee at al. 2011). It is also important to realize that municipal companies also carry out so-called ancillary economic activity alongside their main activity. The objectives of both types of activities differ in terms of profitability. The objective of the main activity is to balance revenues and expenses, whereas the objective of the ancillary economic activity is profit. Therefore, the BAMF model includes three indicators linked with profitability that are designed with regard to the specifics of municipal companies.

An indicator supporting the assessment of profitability, or rather the performance side of efficiency is the performance indicator, marked with $P e$, see formula (7). This indicator is based on the general concept of added value as a "value added through processing". The accounting added value is calculated as the sum of sales margins and outputs reduced by inputs. In the accounting of municipal companies, among which contributory 
organizations belong as the most common legal form in the Czech Republic, the added value is determined as the total revenue (including operating subsidies) reduced by expenses posted to account groups 50 and 51. Personnel costs are covered by account group 52, depreciation represented by the amount posted to account 551 (CR 2009). The structure of this sub-indicator is based on the consideration that includes the elements into which the added value breaks down, i.e. a newly created value allocated to the personnel of the entity (personnel costs), to lenders (interest), to the state (taxes) and to the entity itself (profit and depreciation accounted for as part of the generated profit). Since we talk about a non-profit organization, which typically does not take a loan and which is exempt from income taxes, the amount of added value in terms of personnel costs and depreciation, i.e. $P e=1$, is "sufficient" when assessing the solvency.

$$
P e=\frac{V A}{P C+D},
$$

where: $V A$ - value added; $P C$ - personnel costs; $D$ - depreciation.

Another indicator of profitability evaluates the relationship between the dynamics of income and expenses. It is the so-called yield variator, here marked with $V y$, see formula (8). The yield variator represents the ratio of a relative increase in revenues in the current period and a relative increase in expenses in the current period. If revenues grow as fast as expenses, then the indicator value is equal to 1 . If revenues grow faster than expenses then the value will be greater than 1 and vice versa. In case of rising expenses and declining revenues we talk about a negative situation; the resulting negative value is then rightly included in the overall evaluation. The situation where revenues grow and at the same time expenses decrease is considered extraordinary. And again (as indeed is the case with every anomaly and negative value of any sub-indicator in the model) the results should be interpreted and the interpretation then becomes part of the overall solvency evaluation of the respective municipal company.

$$
V y=\frac{\Delta R / R}{\Delta E / E},
$$

where: $R$ - revenue; $E$ - expenses.

For the evaluation of the profitability of municipal companies that implemented ancillary economic activity in addition to their main activity we use an indicator marked with $P r$, see formula (9). The loss is reported in absolute value. The ratio of the profit from the ancillary activity and loss from the main activity is increased by 1 with respect to the BAMF model concept. According to past experience it is possible to disregard an alteration of cases where profit from the ancillary activity covers loss from the main activity by more than $100 \%$. These are not common cases, and if they occur, then the overall effect on the solvency indicator is not excessive. A loss from an ancillary activity is not taken into account as ancillary activities should not be loss-making (for the completeness of the model this indicator is also mentioned, but due to the lack of economic activities it is not applied to the financial health analysis of emergency medical services providers). 


$$
\operatorname{Pr}=\frac{P A A}{L M A}+1,
$$

where: $P A A$ - profit from an ancillary activity; $L M A$ - loss from the main activity.

The evaluation was carried out for 14 regional providers of emergency medical services for the period of 2010-2014, i.e. five years. It is based on 336 values for sub-indicators. For one year, due to the lack of data, the activity indicator was not evaluated; the aggregate BAMF indicator then took this fact into consideration.

Confirmation of the hypotheses is associated by authors to the fulfilment of the following conditions:

- for the hypothesis i) "providers of emergency medical services in the Czech Republic demonstrate financial health as measured by the aggregate BAMF indicator", it is necessary that the aggregate BAMF indicator does not deviate from the reference value 1 by more than 0.5 , i.e. it falls into the tolerance interval of $<-0.5 ; 1.5>$, both on average during the reporting period and also in each year for each provider;

- for the hypothesis ii) "variability of the aggregate financial health indicator is low" it is assumed that the coefficient of variation in each year does not exceed $20 \%$;

- for the hypothesis iii) "variability of each sub-indicator is also low" this applies by analogy, i.e. coefficient of variation in each year does not exceed $20 \%$.

(The level of $20 \%$ was selected both with regard to the existing experience from a similar type of analyses where the variation coefficient takes positive values; secondly, it is the free use of the 5-point Likert scale).

In the presence of extreme values, which show as deviations exceeding ten times the reference value in the case of sub-indicators and five times for the aggregate indicator, the applicability of the model is tested in the variant that eliminates these extreme values.

\section{Results and discussion}

The results are divided into two parts simulating the management assessment of the situation. First, the overall results are assessed, i.e. the aggregate indicator, the BAMF model output, its level and variability. Consequently, the focus is on the results of the sub-indicators comparing their level and their variability in different years and among various providers. The occurrence of extreme values leads to the analysis of their causes.

\subsection{The overall result: the level and variability}

In terms of the level of achieved values of the aggregate financial health indicator there was a deviation observed in 4 cases out of 70: a positive deviation in two years in the Moravian-Silesian Region where the BAMF indicator reached the value of 1.53 in 2013, and even 1.90 in 2014; by contrast, in two regions negative values were reached, which in terms of the definition (five times the reference value) represent extreme values. They were the Hradec Kralove Region with a value of -6.09 in 2014 and the Karlovy Vary Region with a value of -13.04 in 2011 . It is obvious that these cases require an analysis of the sub-indicators, or the data entered. 
Table 1 presents the chosen characteristics of a set of selected data with a focus on the measurement of variability. The table shows that the presence of extreme values leads to increased variability, which exceeds the limit required for the fulfilment of low variability assumption (in 2011, the coefficient of variation reached about 3,930\%, in 2014, more than 276\%); the extreme value of the Karlovy Vary Region in 2011 affects the average value of the set so much that it exceeds the tolerance interval specified for the assessment of individual providers. The elimination of outliers, however, leads to a result which indicates the low variability of the set. Thus, once again the need to analyze the causes of the observed extreme values comes to the fore.

Table 1. Selected characteristics of aggregate BAMF indicator

\begin{tabular}{ccccccccc}
\hline & \multicolumn{3}{c}{ BAMF incl. outliers } & \multicolumn{3}{c}{ BAMF excl. outliers } \\
\cline { 2 - 9 } Year & Max & Min & $\begin{array}{c}\text { Coef. of } \\
\text { variation }\end{array}$ & Average & Max & Min & $\begin{array}{c}\text { Coef. of } \\
\text { variation }\end{array}$ & Average \\
\hline 2010 & 1.4548 & 0.7513 & 0.1712 & 1.1362 & 1.4548 & 0.7513 & 0.1712 & 1.1362 \\
\hline 2011 & 1.4042 & -13.0414 & 39.3041 & 0.0928 & 1.4042 & 0.8903 & 0.1511 & 1.1031 \\
\hline 2012 & 1.4257 & 0.9071 & 0.1345 & 1.1374 & 1.4257 & 0.9071 & 0.1345 & 1.1374 \\
\hline 2013 & 1.5339 & 0.8607 & 0.1608 & 1.1244 & 1.5339 & 0.8607 & 0.1608 & 1.1244 \\
\hline 2014 & 1.9007 & -6.0919 & 2.7633 & 0.6852 & 1.9007 & 0.8943 & 0.1961 & 1.2065 \\
\hline
\end{tabular}

Source: Author's own work based on AZZS data (2015).

\subsection{Partial results: the level and variability}

The comparison of the values of individual sub-indicators brings to interesting results. When applying similar tolerance limits as for the overall BAMF indicator, the liquidity indicator diverges in a positive direction, which means that the value of the aggregate BAMF indicator usually improves. We talk about 44 cases out of 70 , but these are not extreme values according to the set limit. At the same time, three regional providers, from Olomouc, Zlin, and the Hradec Kralove Region, do not exceed the defined tolerance interval in any of the monitored years. Indicators of activity, autarchy, and performance show no extreme values and they exceed the defined tolerance interval only rarely: in the case of the activity indicator in 4 cases out of 56; autarchy and performance indicators always moved within the tolerance interval and looking at the minimum and maximum values listed in Table 2, a considerable proximity to the reference value is apparent. However, it should be noted that the activity indicator usually reached values below the reference value "1", i.e. decreased the value of the aggregate BAMF indicator.

It appears that the problematic indicator, which displays extreme values, is the yield variator. Although it exceeded the tolerance interval, which had been set for the aggregate indicator, only in 8 cases out of 70 (three of which are recognized as maximum values and three as minimum values in separate years in Table 3), two of them are extreme values, which significantly exceeded the defined limit of ten times the reference value. A closer look at the financial data reveals that in the case of the Karlovy 
Vary Region provider the yield variator reached -70.2386 in 2011 , which was due to a decline in revenue by about 4.5 percentage points, caused by the lower contribution from the founder and lower other income, which even higher revenues from health insurance companies, compared with the previous year, did not manage to eliminate; at the same time there was a slight increase in overall expenses (by about 0.07 percentage points), caused mainly by higher expenses for fuel and purchased services. In the case of the Hradec Kralove Region provider the yield variator value was at -34.4505 , which was due to a very rare occurrence, namely, a slight increase in revenues by about 0.5 percentage points and at the same time a reduction in expenses; although only by 0.015 percentage points, the variator, which was designed as a form of sensitivity indicator, clearly pointed to this relative change in the value of compared indicators.

Table 2. Selected characteristics of liquidity, activity, autarchy, and performance indicators

\begin{tabular}{|c|c|c|c|c|c|c|c|c|}
\hline \multirow[b]{2}{*}{ Year } & \multicolumn{4}{|c|}{ Liquidity } & \multicolumn{4}{|c|}{ Activity } \\
\hline & Max & Min & $\begin{array}{l}\text { Coef. of } \\
\text { variation }\end{array}$ & Average & Max & Min & $\begin{array}{l}\text { Coef. of } \\
\text { variation }\end{array}$ & Average \\
\hline 2010 & 2.9119 & 0.8671 & 0.3611 & 1.7375 & . & . & . & . \\
\hline 2011 & 3.2417 & 0.9745 & 0.3877 & 1.8151 & 1.3816 & 0.4508 & 0.2758 & 0.7665 \\
\hline 2012 & 3.4924 & 1.0558 & 0.3417 & 1.8822 & 1.4818 & 0.4204 & 0.3239 & 0.8032 \\
\hline 2013 & 3.8735 & 0.9553 & 0.4361 & 1.9651 & 1.2806 & 0.4078 & 0.2992 & 0.7645 \\
\hline 2014 & 3.5932 & 0.8664 & 0.3707 & 2.0122 & 1.0691 & 0.5661 & 0.2171 & 0.7839 \\
\hline \multirow[b]{2}{*}{ Year } & \multicolumn{4}{|c|}{ Autarchy } & \multicolumn{4}{|c|}{ Performance } \\
\hline & Max & Min & $\begin{array}{l}\text { Coef. of } \\
\text { variation }\end{array}$ & Average & Max & Min & $\begin{array}{l}\text { Coef. of } \\
\text { variation }\end{array}$ & Average \\
\hline 2010 & 1.0122 & 0.9996 & 0.0034 & 1.0019 & 1.0705 & 1.0063 & 0.0167 & 1.0243 \\
\hline 2011 & 1.0026 & 0.9544 & 0.0120 & 0.9973 & 1.0346 & 0.9655 & 0.0153 & 1.0131 \\
\hline 2012 & 1.0274 & 1.0000 & 0.0073 & 1.0036 & 1.0929 & 1.0051 & 0.0224 & 1.0275 \\
\hline 2013 & 1.0192 & 1.0000 & 0.0061 & 1.0034 & 1.0854 & 0.9921 & 0.0231 & 1.0187 \\
\hline 2014 & 1.0075 & 0.9976 & 0.0023 & 1.0014 & 1.0380 & 1.0027 & 0.0104 & 1.0158 \\
\hline
\end{tabular}

Source: Author's own work based on AZZS data (2015).

Table 3. Selected characteristics of yield variator

\begin{tabular}{llllllllll}
\hline Year & \multicolumn{2}{l}{ Incl. outliers } & \multicolumn{7}{c}{ Excl. outliers } \\
\cline { 2 - 9 } & Max & Min & $\begin{array}{l}\text { Coef. of } \\
\text { variation }\end{array}$ & Average & Max & Min & $\begin{array}{l}\text { Coef. of } \\
\text { variation }\end{array}$ & Average \\
\hline 2010 & 1.2891 & -0.4718 & 0.5054 & 0.8246 & 1.2891 & -0.4718 & 0.5054 & 0.8246 \\
\hline 2011 & 1.6388 & -70.2386 & -4.5282 & -4.0540 & 1.6388 & 0.8522 & 0.1770 & 1.0372 \\
\hline 2012 & 1.771 & 0.9297 & 0.1906 & 1.0663 & 1.771 & 0.9297 & 0.1906 & 1.0663 \\
\hline 2013 & 1.2626 & 0.7453 & 0.1160 & 1.0027 & 1.2626 & 0.7453 & 0.1160 & 1.0027 \\
\hline 2014 & 3.2503 & -34.4505 & -7.0587 & -1.3052 & 3.2503 & 0.5613 & 0.5114 & 1.2444 \\
\hline
\end{tabular}

Source: Author's own work based on AZZS 2015 data. 
The variability evaluation of the BAMF model sub-indicators using the coefficient of variation indicates low variability in autarchy and performance indicators. In the case of the other three indicators this assumption has not been confirmed. The coefficient of liquidity variation was around 34 to $44 \%$, the coefficient of variation of activity ranging from about 20 to $33 \%$; and even though we took into account the yield variator indicator without outliers the variation coefficient in this case still did not display low variability, as the variation coefficient of the selected values, although ranging from about 12 , almost reached $51 \%$.

\section{Conclusions}

The emergency medical service represents a specific public product, the cost of which is determined not only by the actual supply of the service, but also by ensuring that the service is available at all times. An important part of effectiveness management in this area is to ensure the financial health of emergency medical service providers, which is organized on a regional basis in the Czech Republic, allowing us to verify the applicability of tools designed for the assessment of financial health through comparisons in time; but also on location, or rather comparing the results of the individual providers of this public service.

As part of this research we evaluated the applicability of the BAMF model as a composite aggregate indicator, consisting of five sub-indicators, whose design takes into account the specifics of public goods producers, or rather public sector entities that can be characterized as municipal companies, representing an original approach to this issue.

Taking into account the results of the research we can say that the BAMF model is applicable and, thanks to its two-level structure it also satisfies the requirement of managerial practice. From the aggregate results, which indicate potential problems, we can proceed to partial results, which reveal problem areas, and if the deviation turns out to be important, then it is necessary to perform a deeper analysis of the causes of these deviations using a detailed look at the financial data and the related sources of information.

In terms of this research the comparability of results was also important. The tested hypotheses concerned deviations from the tolerance interval linked to the model reference value. The application of the BAMF model proved that it is easy to find the causes of extreme values. Thanks to its relative simplicity the model makes partial modification possible without losing the interpretability of the results.

The fact that the variability of the aggregate BAMF indicator and its components did not prove to be low within the set limit (with the exception of autarchy and performance) indicates that there is a significant potential for benchlearning, which may be implemented within a group of emergency medical service providers, but also their founders, in order to increase their financial health and effectiveness.

\section{Funding}

This work was supported by the University of Pardubice, Faculty of Economics and Administration [grant number SGSFES_2015001]. 


\section{Disclosure statement}

The authors hereby declare they have no competing financial, professional, or personal interests from other parties.

\section{References}

Altman, E. I. 1968. Financial ratios, discriminant analysis and the prediction of corporate bankruptcy, Journal of Finance 23(4): 589-609. https://doi.org/10.1111/j.1540-6261.1968.tb00843.x

Altman, E. I. 2002. Corporate distress prediction models in a turbulent economic and Basel II environment, [online], [cited 30 October 2015]. NYU Working Paper No. S-CDM-02-11. Available from Internet: http://ssrn.com/abstract $=1295810$

Andrés Alonso, P.; Lopez Iturriaga, F. J.; Rodrigues Sanz, J. A. 2005. Financial decisions and growth opportunities: a Spanish firm's panel data analysis, Applied Financial Economics 15: 391-407. https://doi.org/10.1080/09603100500039201

AZZS. 2015. ZZS $\check{C} R v$ čislech [EMS Czech Republic in figures]. [online], [cited 30 October 2015]. Available from Internet: http://www.azzs.cz/dokumenty/zzs-cr-v-cislech/

Balcaen, S.; Ooghe, H. 2006. 35 years of studies on business failure: an overview of the classic statistical methodologies and their related problems, The British Accounting Review 38: 63-93. https://doi.org/10.1016/j.bar.2005.09.001

Beria, P.; Giove, M.; Miele, M. 2012. A comparative analysis of assessment aproaches. Six cases from Europe, International Journal of Transport Economics 39(2): 185-217.

Borins, S. 2001. Encouraging innovation in the public sector, Journal of Intellectual Capital 2(3): 310-319. https://doi.org/10.1108/14691930110400128

Booth, L. 2007. Capital cash flows, APV and valuation, European Financial Management 13(1): 29-48. https://doi.org/10.1111/j.1468-036X.2006.00284.x

Bovaird, T.; Loffler, E. 2003. Evaluating the quality of public governance: indicators, models and methodologies, International Review of Administrative Sciences 69(3): 313-328.

https://doi.org/10.1177/0020852303693002

CR. 2011. Act No. 374/2011 Coll., on emergency medical services, as amended, [online], [cited 30 October 2015]. Available from Internet: https://portal.gov.cz

CR. 2009. Decree No. 410/2009 Coll. implementing some provisions of act No. 563/1991 Coll., on accounting, as amended, for some selected entities, [online], [cited 30 October 2015]. Available from Internet: https://portal.gov.cz

Daler, J. 2016. Komparace českého a estonského systému zdravotního a nemocenského pojištění [Comaprison of Czech and Estonian system(s) of health and sickness insurance], Scientific Papers of the University of Pardubice, Series D 36(1): 66-78.

Doucha, R. 1996. Finanční analýza podniku [Corporate financial analysis]. Praha: Vox Consult. Foo, C. Y.; Lim, K. K.; Sivasampu, S.; Dahian, K. B.; Goh, P. P. 2015. Improving the effectiveness of service delivery in the public healthcare sector: the case of ophthalmology services in Malaysia, BMC Health Services Research 15: 349-358. https://doi.org/10.1186/s12913-015-1011-0

Galariotis, E.; Guyot, A.; Doumpos, M.; Zopounidis, C. 2015. A novel multi-attribute benchmarking approach for assessing the financial performance of local governments: empirical evidence from France, European Journal of Operational Research 248: 301-317.

https://doi.org/10.1016/j.ejor.2015.06.042

Gordon, M. J. 1959. Dividends, earnings, and stock prices, The Review of Economics and Statistic 41(2): 99-105. https://doi.org/10.2307/1927792 
Gwee, E.; Curie, G.; Stanley, J. 2011. International variation in cost-benefit analysis of urban rail projects impact on outcomes, Transportation Research Record 2261: 73-85.

https://doi.org/10.3141/2261-09

Halaskova, M.; Halaskova, R. 2014. Assessment of public expenditures in selected areas of public services in EU countries, in 14th International Conference on Finance and Banking, 16-17 October, 2013, Karvina, Czech Republic, 88-98.

IPSASB. 2016. Handbook of international public sector accounting pronouncements. IPSAS 1Presentation of financial statements, [online], [cited 05 August 2016]. Available from Internet: http://www.ifac.org/publications-resources/2016-handbook-international-public-sector-accounting-pronouncements

Jackson, P. M.; Brown, C. V. 2003. Ekonomie veřejného sektoru [Public sector economics]. Praha: Eurolex Bohemia.

Janosikova, L.; Gabrisova, L.; Jezek, B. 2015. Load balancing location of emergency medical services station, E\&M Economics and Management 18(3): 30-40.

https://doi.org/10.15240/tul/001/2015-3-003

Kouzmin, A.; Löffler, E.; Klages, H.; Korac-Kakabadse, N. 1999. Benchmarking and performance measurement in public sectors: towards learning for agency effectiveness, International Journal of Public Sector Management 12(2): 121-144. https://doi.org/10.1108/09513559910263462

Kraftová, I. 2002. Finanční analýza municipální firmy [Financial analysis of municipal companies]. Praha: C.H.Beck.

Kraftová, I. 2007. Efektivnost veřejného sektoru regionu na mikroúrovni: modifikovaný model BAMF [Effectiveness of public sector on the micro-level: a modified BAMF model], in 2nd Central European Conference in Regional Science, 10-13 October 2007 Novy Smokovec, Slovak Republic, 452-463.

Kraftová, I.; Sustrova, E. 2010. Mezoekonomické aspekty cyklického charakteru bankrotu v ČR [Meso-economic aspects of the cyclical nature of bankruptcies in the Czech Republic], Scientific Papers of the University of Pardubice, Series D 18(2): 125-137.

Kubenka, M.; Kralova, V. 2013. Využití Z' score při hodnocení finančního zdraví odvětví stavebnictví [Z" score in assessing the financial health in the construction sector], E\&M Economics and Management 16(1): 101-112.

Marianov, V.; Taborga, P. 2001. Optimal location of public health centres which provide free and paid services, Journal of the Operational Research Society 52: 391-400.

https://doi.org/10.1057/palgrave.jors.2601103

Mastalka, M.; Saldova, B. 2015. Changes in regional structure of medical facilities in the Czech Republic, in 18th International Colloquium on Regional Sciences, 17-19 June 2015, Hustopece, Czech Republic, 421-426.

Mrkvicka, J. 2006. Finanční analýza [Financial analysis]. 2nd ed. Praha: ASPI.

Neumaierova, I.; Neumaier, I. 1995. Zkuste spočítat svůj index IN [Try to calculate your IN index], Terno 5: 7-10.

Ruckova, P. 2014. Analysis of the relation between liquidity and selected indicators from the view of solvency in selected business branches, in 14th International Conference on Finance and Banking, 16-17 October 2013, Ostrava, Czech Republic, 354-365.

Sullivan, H.; Gillanders, G. 2005. Stretched to the limit? The impact of local public service agreements on service improvement and central-local relations, Local Government Studies 31(5): 555-574. https://doi.org/10.1080/03003930500293450

Taffler, R. J. 1982. Forecasting company failure in the UK using discriminant analysis and financial ratio data, Journal of the Royal Statistical Society, Series A (general) 145(3): 342-358. https://doi.org/10.2307/2981867 
Tamari, M. 1966. Financial ratios as a means of forecasting bankruptcy, Management International Review 6(4): 15-21.

Wang, D.; Qi, C.; Wang, H. 2014. Improving emergency response collaboration and resource allocation by task network mapping and analysis, Safety Science 70: 9-18.

https://doi.org/10.1016/j.ssci.2014.05.005

Ivana KRAFTOVÁ. The author is a member of the Institute of Regional and Security Sciences, Vice-Dean of the Faculty of Economics and Administration at the University of Pardubice, the Czech Republic. At the beginning of her academic career, she focused on the financial management of private- and public-sector economic subjects. Recently, she has paid attention to meso-economic issues regional and branch-oriented - in the context of regional development and security.

Lenka KAŠPAROVÁ. The author is a student of the Faculty of Economics and Administration at the University of Pardubice, the Czech Republic. She focuses the issues of regional development, especially security of regions. 